\title{
CHRYSOBERYL AND ALEXANDRITE FROM THE PEGMATITE DISTRICTS OF MINAS GERAIS, BRAZIL
}

\author{
By Keith Proctor
}

This fourth article in the author's series on the pegmatite districts of Minas Gerais, Brazil, focuses on chrysoberyl, particularly the rare but coveted varieties cat's-eye and alexandrite. Most of the cat's-eye chrysoberyls on the gem market today come from Brazil, primarily from the region around the Americana and Santana valleys. This article examines some of the more important mines in this region, with a detailed description of the Barro Preto deposit. Farther south, the Malacacheta area has produced a number of fine alexandrites during the last 13 years. Since October 1986, however, it has been overshadowed in both quality and quantity by the small Lavra de Hematita, which produced $50 \mathrm{~kg}$ of fine alexandrite in less than three months. These two occurrences are also described in detail.

\section{ABOUT THE AUTHOR}

Keith Proctor is president of Keith Proctor Precious Gems, a wholesale import firm in Colorado Springs, $\mathrm{CO}$.

Acknowledgments: Special thanks to H. Kennedy. A. Tavares, and Dr. R. Nash, without whose help this article would not exist. The input of the following is greatly appreciated: K. Elawar, W. Brennan, S. Domingos, Dr. H. Bank, Dr. K. Schmetzer, Dr. F. Pough, Dr. E. Gübelin, S. Watt, C. Bank, Dr. J. Raggi, Dr. D. Schwartz, J. Drew, and O. Neto. Thanks also go to L. Moffett for typing the manuscript, to L. Rayburn for translations, and especially to Mauna Proctor for her help in translaling. typing, and editing and for her constant support.

(c) 1988 Gemological Institute of America
$\mathrm{T}$ he two commercially most important gem varieties of chrysoberyl-cat's-eye chrysoberyl and alexandriteare among the world's rarest gemstones (figure 1). The state of Minas Gerais, Brazil, and the island of Sri Lanka are presently the world's two largest suppliers of chrysoberyl, cat's-eye chrysoberyl, and alexandrite, although Russia historically has produced some fine material. Since production from Sri Lanka has dropped off dramatically in recent years and the classic Uralian deposits are most likely exhausted, the major future production will probably come from Brazil.

Chrysoberyl, with a hardness of $81 / 2$, is the third hardest of the gemstones, following only diamond and corundum. Known in antiquity but not properly identified, chrysoberyl was found mixed with tourmaline and other gems in the gem gravels of Ceylon by at least the late 1600s. In Ceylon, the Singhalese natives considered chrysoberyl a superior kind of tourmaline (Ball, 1930). The name (chryso-, from Greek for yellow or golden, plus beryl) indicates that other, more sophisticated investigators considered chrysoberyl to be a variety of beryl (Sinkankas, 1964). It was finally chemically identified as a distinct species by Werner in 1789, and chrysoberyl with the chatoyant, or "cat's-eye" effect, was dubbed "cymophane" by Haüy in 1798 (Bauer, 1904; Bank, 1973).

Brazil was recognized early on as a major source, with the first mining exports (probably from the Araçuai and Minas Novas districts) occurring by 1805 . A huge-almost $8 \mathrm{~kg}$-chrysoberyl was listed as one of the treasures of Rio de Janeiro in 1828 (Bauer, 1904; Ball, 1930). Brazilians have long coveted chrysoberyl, which they called "crisólita," and even named the city of Crisólita (probably another early source) after the gem. Today, Minas Gerais is the major source of chrysoberyl in Brazil. The Brazilian chrysoberyls range in color from yellow to yellowish green, olive green, gold, brown, and, rarely, "ruby" red (figure 2). 


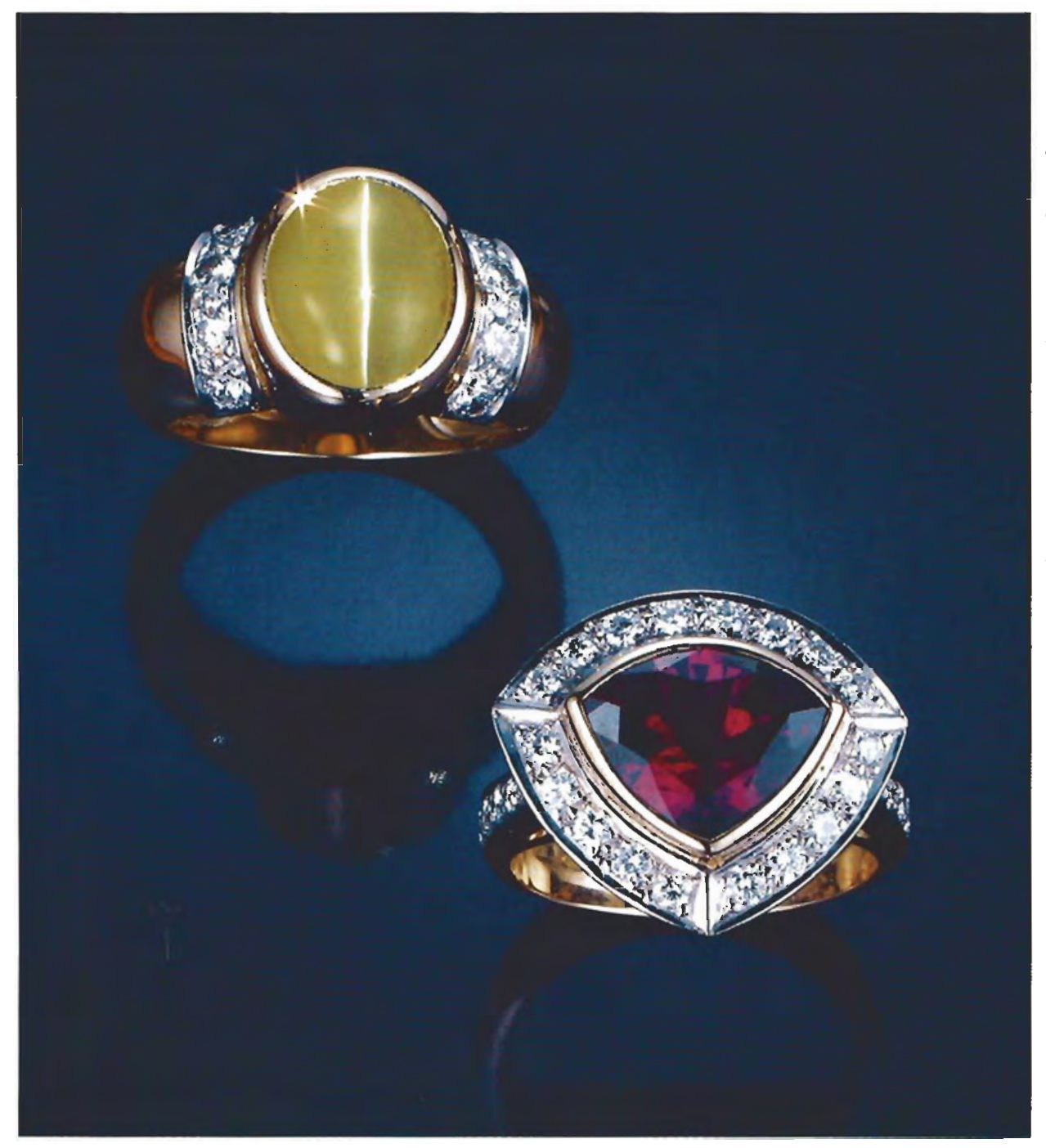

Figure 1. Minas Gerais is a major source of fine cat's-eye chrysoberyl and alexandrite. The "honey"-colored cat's-eye chrysoberyl shown here (5.47 ct) is from the Americana/Santana valley region; the alexandrite $(3.03 \mathrm{ct})$, which appears red in incandescent light (here) and bluish green in fluorescent light, is from the newest deposit, Lavra de Hematita. Rings courtesy of Silverhorn, Santa Barbara, CA; photo (C) Tino Hammid.

The color-change variety of chrysoberyl, alexandrite, was discovered in the Ural Mountains of Russia in 1830; it was named after the heirapparent to the Russian throne, the future Alexander II. The best Russian stones tend to be bluish green in daylight (or fluorescent light) and pink, reddish purple (raspberry), or, rarely, "ruby" red in incandescent light (Pough, 1976). Most of the Brazilian alexandrites discovered before October 1986 are also green in daylight but are more amethystine or pink in incandescent light (Kunz, 1913; Pough, 1973). However, the best gems from the newly discovered Lavra de Hematita (also known as Nova Era or Itabira) alexandrite deposit are predominantly bluish green to greenish blue (called pavão in Brazil) in daylight and pink, raspberry, "rhodolite," or "ruby" red in incandescent light (figure 3). The rarest of the rare alexandrites is fine cat's-eye alexandrite.
In the almost 200 years since chrysoberyl was first mined in Brazil, many tens of thousands of carats of chrysoberyl, cat's-eye chrysoberyl, and alexandrite have been taken from deposits in northeast Minas Gerais and the states of Bahia and Espirito Santo. At least $95 \%$ of the chrysoberyl and cat's-eye chrysoberyl found in Minas Gerais in recent years has come from the many deposits in the Santana and Americana valleys, near the city of Padre Paraíso in the Teófilo Otoni-Marambaia pegmatite districts (K. Elawar, H. Kennedy, A. Tavares, pers. comm., 1987; figure 4). The Barro Preto and Gil claims, as well as the Faísca and Cilindro deposits, are particularly notable. Virtually all of the finest alexandrite produced in the last 13 years has been mined from the pegmatite regions associated with the cities of Malacacheta and Itabira. In these two areas, the Córrego do Fogo and Hematita deposits are major producers for the 


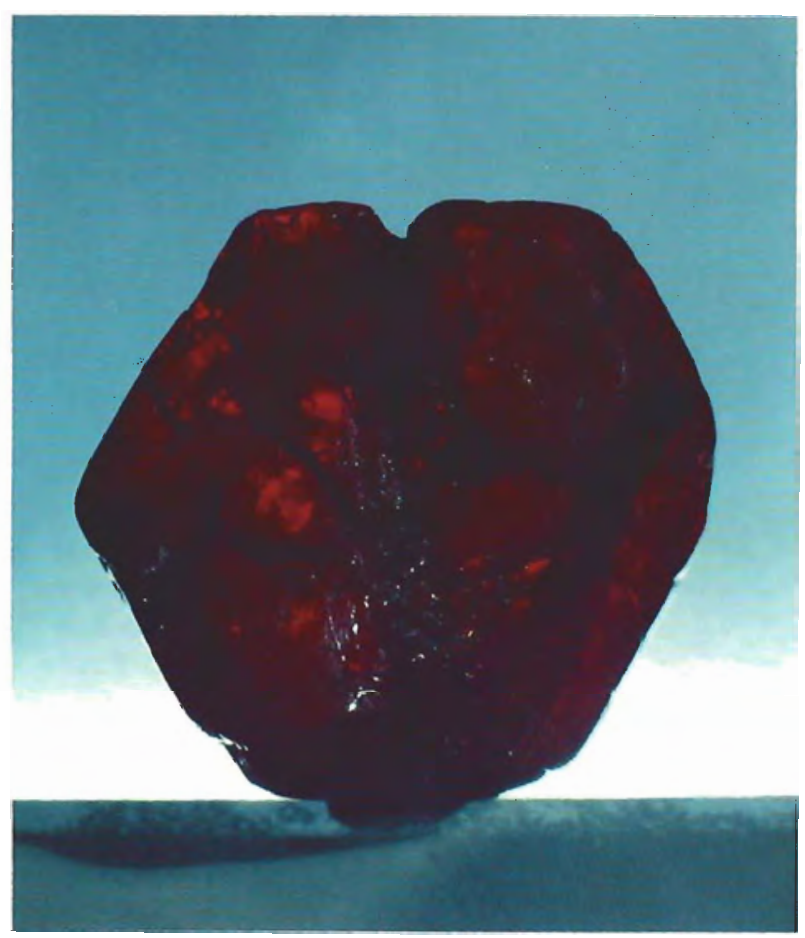

Figure 2. This 41-ct twinned crystal, found at Malacacheta in 1976, is a rare example of red chrysoberyl. Courtesy of Henry Kennedy, Teófilo Otoni, Brazil; photo $\odot$ Fred L. Elsnau.

world market. These deposits and the gems they produce are described below.

The reader is referred to part 1 of this series (Proctor, 1984) for a detailed description of the pegmatite deposits of Minas Gerais, the terminology used to describe these gem deposits, and the various mining methods used. To the author's knowledge, the various types of chrysoberyl are not being subjected to any form of color or phenomenon enhancement.

\section{CHRYSOBERYL FROM THE AMERICANA AND SANTANA VALLEYS}

As early as 1846 , chrysoberyl was reported from Córrego de Santa Anna (probably the Santana valleyl, east of Araçuaí, by Van Helm Reischen. The earliest record of cat's-eye chrysoberyl in this region comes from Dr. Hermann Bank, whose father observed them when he visited the Americana valley on horseback in 1910. Not knowing what they were, the local cattle ranchers had been throwing the gems away ( $\mathrm{H}$. Bank, pers. comm., 1988).

In rare instances, fine alexandrites have been found in the Americana valley. The earliest report is of a 10-ct gem that was cut in 1932; a notable find also occurred in 1975 (H. Bank, pers. comm., 1984). The Santana valley has produced only a few pale alexandrites with poor color change from near the junction of the Barro Preto and Gil creeks $[\mathrm{H}$. Kennedy, pers. comm., 1987).

The following discussion provides what little information is available on the Faísca and Cilindro mines, in the Americana valley, and a detailed description of the mining operation at Barro Preto (with reference to the nearby operation at Gil), in the Santana valley.

Location and Access. These two valleys lie east of and roughly parallel to highway BR-116 (figure 4). The western valley is the watershed for the Santana River, which runs directly south from near Padre Paraíso; the parallel eastern valley is the watershed for the Americana River. The two valleys are separated by a ridge of hills, which is probably the original source of the chrysoberyls. Numerous streams that flow into these two rivers cut smaller valleys along both sides of this range of hills. It is within these smaller valleys that the chrysoberyls are found.

These chrysoberyl-bearing valleys may be reached by traveling north from Teofilo Otoni on BR-116 to $\mathrm{km}$ marker \#175 (indicating the distance remaining to the Bahia border), $5 \mathrm{~km}$ northeast of Padre Paraíso. To reach the Gil and Barro Preto claims, one then takes a good dirt road east almost $10 \mathrm{~km}$, toward the city of Águas Formosas. Just before reaching the hamlet of Ribeirão de Santana, take the road south into the Santana valley approximately $7 \mathrm{~km}$ to reach the Gil and Barro Preto creeks. To reach the Faísca and Cilindro garimpos for workings, used to refer to a specific series of pits in the alluvium), instead of turning south at the $10 \mathrm{~km}$ junction one continues for an additional $18 \mathrm{~km}$ east and then turns south on another dirt road to the mining area, which lies along the Faísca and Topázio streams, two tributaries of the Americana River.

The Faísca and Cilindro Mines. Since 1939, Rudolf Ziemer and his family have mined relatively large quantities of chrysoberyl and cat's-eye chrysoberyl, and minor amounts of alexandrite as well as some topaz, from the Faísca mine (also known as the Ziemer minel in the Americana valley. Ziemer's son (also named Rudolf) mechanized 
parts of Barro Preto (H. Kennedy, pers. comm., 1988):

1. A red lateritic soil overburden.

2. An organically rich layer of black clay mixed with sand that is up to $1.25 \mathrm{~m} / 4 \mathrm{ft}$.) thick (found only occasionally in the Gil valley; barro preto means black clay).

3. An upper cascalho layer of gem pebbles mixed with sand and rounded rocks that lies above the present creek level. This gravel layer is reddish brown from iron-oxide staining, and varies from
$5 \mathrm{~cm}$ (at which point it contains no gems) to $1 \mathrm{~m}$ thick. A thicker layer with good-sized quartz gravel is a strong indicator that gem material is present. Approximately $15-20 \%$ of the gem chrysoberyls produced at Barro Preto, more than $90 \%$ of which have sharp broken edges or crystal faces, are found in this layer. This appears to be a colluvial layer that has weathered out of a nearby source and been eroded into this narrow valley (see Proctor, 1984, for a discussion of colluvial/alluvial deposits).

Figure 4. The Americana and Santana valleys have produced approximately 95\% of the chrysoberyl and cat's-eye chrysoberyl found in Minas Gerais during the last 50 years. The major deposits are identified. See the first article in this series (Proctor, 1984) for a map of all the major gem pegmatite mines in northeastern Minas Gerais. Artwork by Jan Newell.

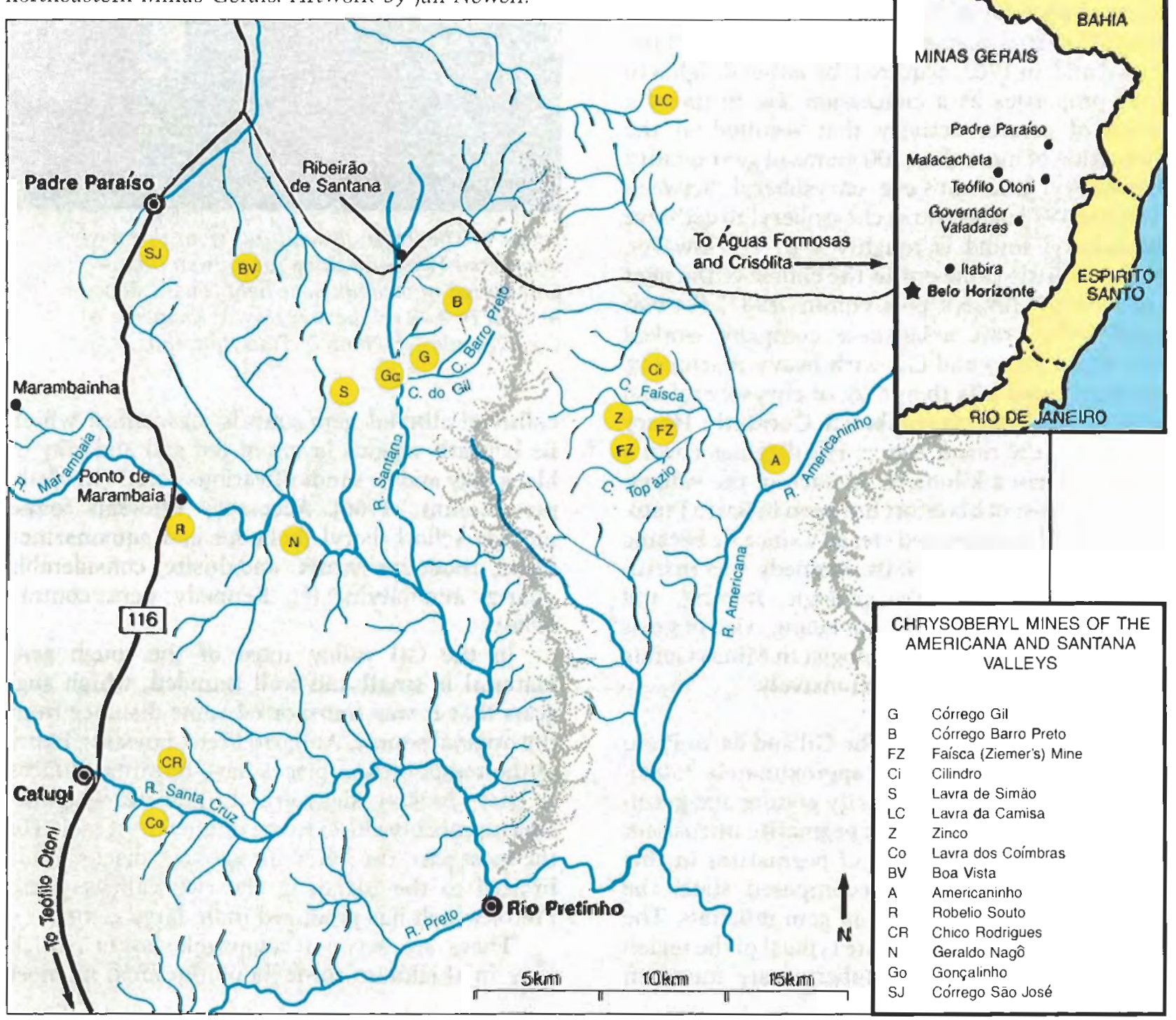




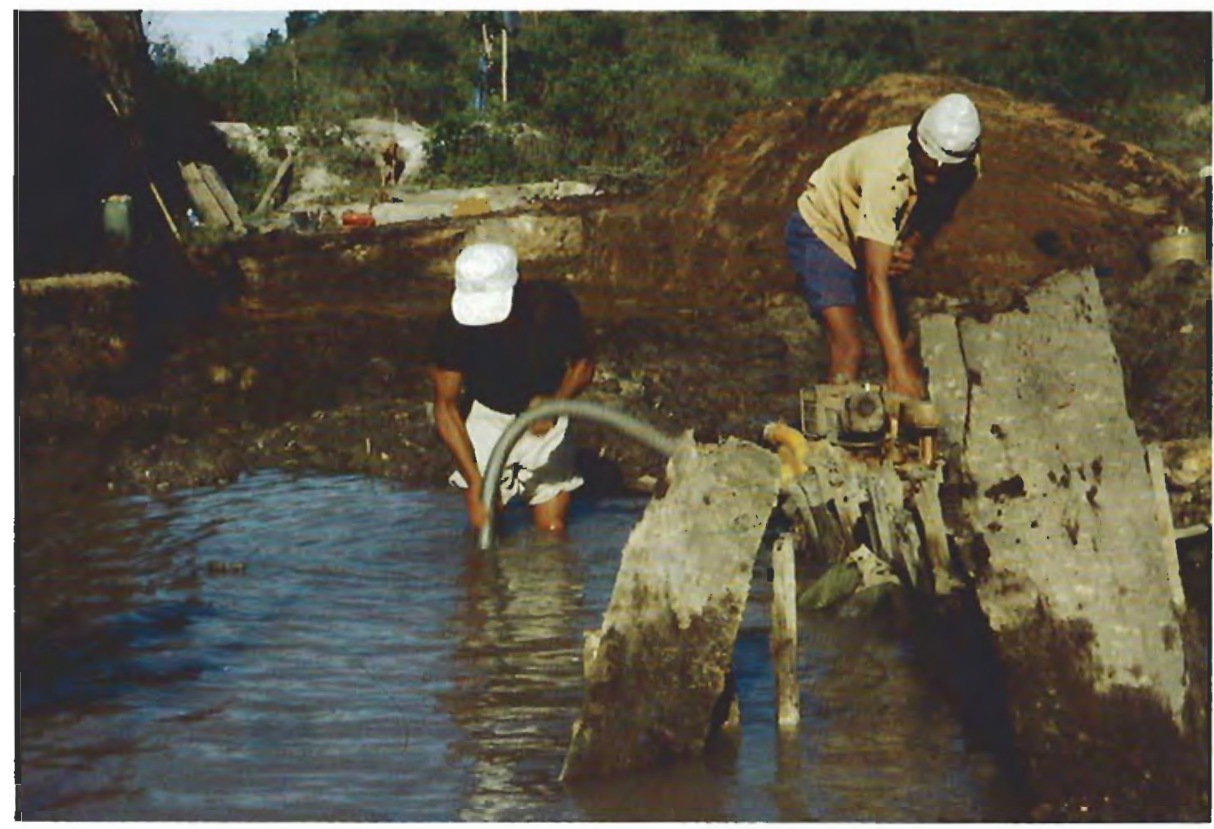

Figure 5. Water is an ongoing problem at Barro Preto. Periodically during the day, the miners must pump the water out in order to gain access to the gembearing gravels. Photo by Henry Kennedy.

4. A black clay (similar to layer no. 2) that contains so much organic matter that, when dried out, it will actually burn like peat. Local geologists suggest that this layer, which blankets the entire valley, resulted from the destruction of a great rain forest. The roots of this forest held back erosion of the surrounding hills; when the forest was destroyed, erosion accelerated rapidly, thus laying down the upper cascalho layer.

5. A gray clay layer from 10 to $20 \mathrm{~cm}(4-8 \mathrm{in}$.) thick that is sometimes extremely hard and is believed to be the product of sedimentation in ancient lakes, ponds, or streams.

6. A fine sand layer of different colors-yellow or red when iron oxide-rich; white if the iron oxide has been leached out - that usually grades into coarser sands as one goes deeper.

7. A lower cascalho layer in which the gems are mixed with coarse, rounded, mostly granite river rocks with perhaps only $10-20 \%$ quartz gravels and some sand (unlike that at the Marambaia and Tres Barras deposits - see Proctor, $1984-$ which is $99 \%$ quartz pebbles).

The color of this cascalho layer varies from white, rose, brown, or orange to gray; it is frequently "braided," with intertwining strands of different colored gravels, each of which probably represents a different creek and different time period. The most productive gem-bearing gravel "braids" are pink and brown; the least productive are white. Tremendous effort is expended in searching for this linha mestra (master gravel). The gravels are cemented into hard masses by a combination of a silica and iron oxides, and must be broken up with long steel bars.

In contrast to the upper, colluvial, gem-bearing layer, the bottom.cascalho is between 0.5 to $1 \mathrm{~m}$ thick and is usually found in the river bottom. As before, the thicker the layer is, the greater its gem potential. In some areas, the chrysoberyls found in this layer are well worn, a truly alluvial deposit. As mining activity moves northwest toward the granite hill, there is a greater concentration of gem chrysoberyls and those recovered show fewer signs of alluvial wear, with complete terminations on some specimens; this material has not moved far from its original source. Approximately $80-85 \%$ of the gem production at Barro Preto comes from this layer.

The altered, decomposed "spongy" gneiss bedrock lies directly under the last cascalho layer, and looks like thick, hard clay, as it does at Marambaia and Tres Barras. The latter deposits, however, each have only one gem-bearing layer.

Because the area is so highly weathered, it is difficult to determine whether the chrysoberyl formed within a pegmatite or in the host rock into which the pegmatites were intruded. However, some gem-quality chrysoberyl has been found in situ in a nearby pegmatite at the Simão mine $(\mathrm{H}$. Kennedy, pers. comm., 1988).

Mining. Hundreds of pits have been dug in these valleys in recent years, but there is a constant problem with water; until pumps were used consistently, little mining progress could be made (figure 5). To find the bottom cascalho layer, 


\section{ALEXANDRITE FROM THE MALACACHETA REGION}

More than 100 (air) $\mathrm{km}$ southwest of Barro Preto lies what for 13 years was one of the few regions in the world that produced fine alexandrite-Malacacheta (also known as Córrego do Fogo or just Fogo). Until the recent discovery at the Lavra de Hematita (discussed below), it was Brazil's foremost producer of this rare gem material.

Figure 10. For 13 years, the Malacacheta region produced some of the finest alexandrite in Brazil. The greatest mining activity was along 8 $\mathrm{km}$ of both sides of the Córrego do Fogo, along $20 \mathrm{~km}$ of the Soturno River, and along a few kilometers of the Setúbal and Setubinha rivers. See the inset map in figure 4 for the location of Malacacheta in relation to the other mining areas discussed in this article. Artwork by lan Newell.

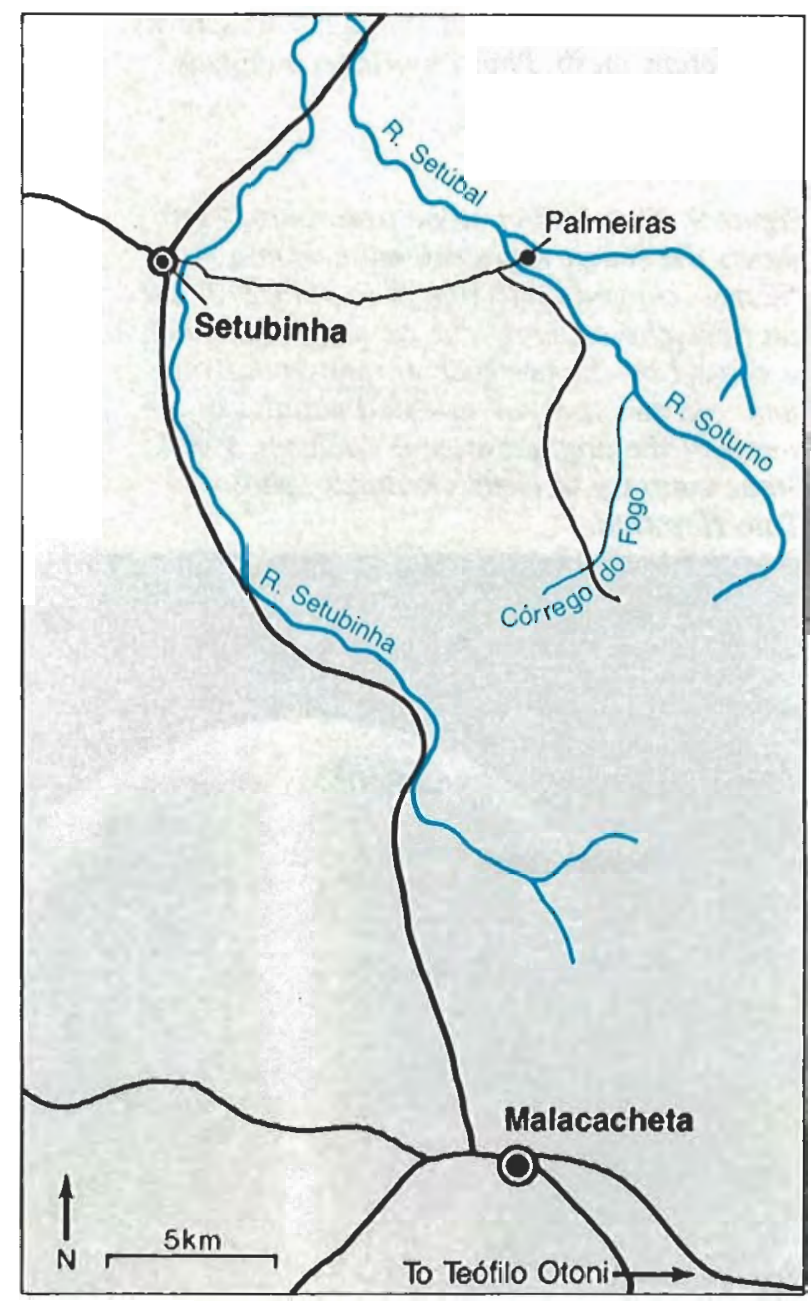

Location and Access. The Malacacheta region is 20 $\mathrm{km}$ directly north of Malacacheta City in the watershed of the Setúbal and Soturno rivers (figure 10). Diggings extend about $8 \mathrm{~km}$ along both sides of Fogo Creek, along $20 \mathrm{~km}$ of the Soturno River, and along a few kilometers of the Setúbal River. Minor deposits have also been found in a small section of the Setubinha River. The valley regions can be reached from the city of Malacacheta by taking a (sometimes impassable) dirt road due north or, more easily, from Setubinha City by taking a dirt road due east to the village of Palmeiras and then south on another dirt road into the valleys.

History. One evening in 1975, João Rodrigues and his sons set up camp along the Fogo Creek. As the sons carried mud from the creek to encase the mandioca roots being prepared for the evening meal, a native fuba, they found nodules of what they thought were green tourmaline. When these were later identified as fine alexandrite, garimpeiros from all over rushed to the region $(\mathrm{H}$. Kennedy, pers. comm., 1987). Over the course of the next 13 years, the search for the rare but very valuable pieces of rough would lead to robberies, claim jumpings, and even several killings.

During the period of peak production, 1980-1982, approximately 4,000 to 5,000 miners worked these valleys. At first, they found relatively productive alluvial deposits along a $150-$ to $300-\mathrm{m}$ wide swath down the Fogo valley encompassing both sides of the creek. The garimpeiros dug the typical square pits to reach the gem-bearing cascalho layer and then shoveled the gravels onto the pit bank. After allowing the pit to fill with waterwhich required about the same time as eating lunch and having a cigarette - the miners waded into the water and used circular screens /called peneiras) to wash the gravels $(\mathrm{H}$. Kennedy, pers. comm., 1987; see Proctor, 1985a, figures 14 and 15, for a similar process).

Geology and Occurrence. All of the alexandrite found to date has been purely alluvial with no insitu occurrences to determine the nature of the original host rock. At the Itabira emerald deposit in Minas Gerais, as at the Goiás and Carnaiba emerald deposits, small amounts of alexandrite have been found in a metamorphic mica-schist with the emeralds. This is also the environment in which alexandrites have been found at the Takowaja River, USSR; Umba River, Tanzania; Fort 
Victoria, Zimbabwe; and at the Transvaal in South Africa (Pough, 1976). There are, however, numerous pegmatites in the Malacacheta region, Further study is needed to determine the exact origin of these deposits.

Production. Since 1975, all of the mining activity has produced only about $2 \mathrm{~kg}$ of very good, mostly clean rough and approximately $6-8 \mathrm{~kg}$ of lesser quality material. Most of this production was alexandrite; very few pieces of "honey"-colored chrysoberyl and cat's-eye chrysoberyl were recovered. The author knows of alexandrite rough as large as 18 grams; the finest faceted stones include a $13 \mathrm{ct}$ and a $15.6 \mathrm{ct}$. A 14.6-gram piece found in the Soturno River in 1985 yielded a superb 18.5-ct cat's-eye alexandrite, one of the world's largest (figure 11). In addition, also in 1985, an 8.1-gram twinned crystal of very rare dark red chrysoberyl (with no color change) was recovered at Córrego do Fogo (again, see figure 2). Limited amounts of very fine, but small $(2-3 \mathrm{ct})$ blue sapphires have been found in these valleys along with some, also small $(2-3 \mathrm{ct})$ gem peridot as well as $50-70 \mathrm{~kg}$ of good rubellite.crystals.

Overall, the alexandrites from Malacacheta are much smaller than those from the Hematita deposit discussed below, because the rough is not as clean or as large. These stones generally are yellowish green in sunlight and pink in incandescent light. The best gems from Malacacheta do not compare with those from Hematita.

The author feels that the Malacacheta region will continue to produce very small quantities of good alexandrites for many years. The most easily accessible and obvious deposits have been extensively but not completely worked. Currently only about 50 garimpeiros are working in this region, not because of a total lack of potentially good areas, but because Hematita is the new El Dorado.

\section{ALEXANDRITE FROM THE LAVRA DE HEMATITA DEPOSIT}

Although the Malacacheta region represents one of the world's great alexandrite locations, in 1987, over a period of less than three months, the size and quality of production from a new discovery called Lavra de Hematita dwarfed its importance. Many prominent dealers and collectors already acclaim this new area as history's greatest alexandrite discovery. To date, Hematita has yielded tens of kilos of alexandrites, including many 10-ct and

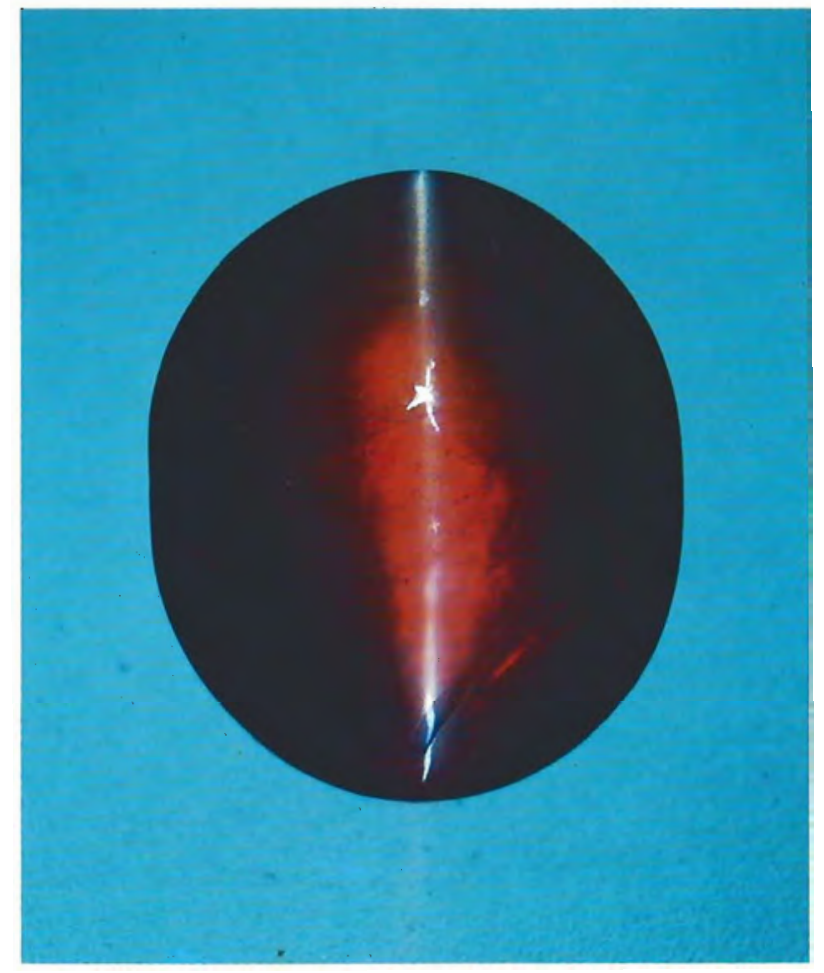

Figure 11. One of the rarest stones to emerge from the Malacacheta region is this $18.5-\mathrm{ct}$ cat's-eye alexandrite. Courtesy of Henry Kennedy; photo (C) Harold e) Erica Van Pelt.

even some 25- and 30-ct clean faceted gems of exquisite beauty that exhibit an extraordinary color change.

Location and Access. The Hematita alexandrite workings can be reached from either Governador Valadares or Belo Horizonte by taking main highway 381 to an unnumbered dirt road that is $15 \mathrm{~km}$ southwest of the city of Antonio Dias and $5 \mathrm{~km}$ northeast of Nova Era; follow this road (which has a sign labeled Hematita) due north $23 \mathrm{~km}$ to the mining area, which is just off the right side of the road and only $3-4 \mathrm{~km}$ southwest of the hamlet of Hematita (figure 12). The mine is correctly called Lavra de Hematita (lavra means mine), but it is also known internationally as Nova Era; most Brazilians refer to it as Lavra de Itabira, or more commonly just Itabira. For the purpose of this article (and to avoid confusion with the Itabira emerald locality, where alexandrites have also been found), Hematita will be used.

History. The history of this discovery begins with two 10-year-old boys, one the son of a local farmer 


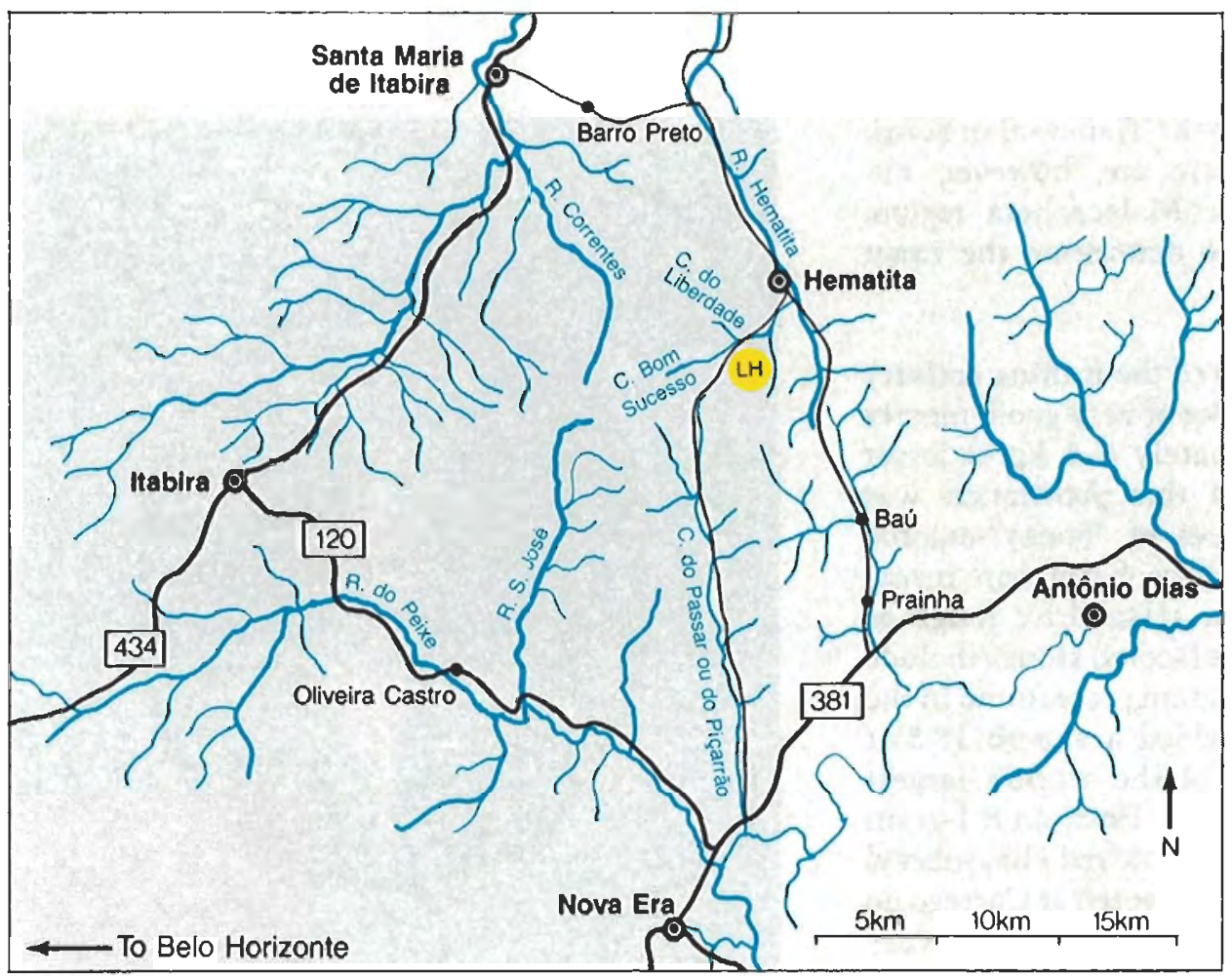

Figure 12. Perhaps the largest deposit of alexandrite ever discovered was found at the Lavra de Hematita ( $L H)$, a small area just southwest of the small town of Hematita in the Itabira mining district. See the inset map in figure 4 for the location of Itabira in relation to the other mining areas discussed in this article. Artwork by Jan Newell.

named Xisto. The boys often played in two brooks that cut through part of the homestead owned by a farmer named Policarpo, which is located within a eucalyptus plantation owned by Ferro Brasileira, an Itabira steel company. (The eucalyptus trees are burned for charcoal that is used to produce steel.) The boys put together a collection of small rough gems that they had found in the creeks, and in October 1986 took them to the nearby city of Santa Maria de Itabira. They sold the stones to a man named Rodazio who, thinking they were andalusite, purchased them for a pittance and told the boys to come back with more if they could. During November, the two boys dug more of the stones, selling some and showing others to Policarpo, Xisto, Socrates /who owns Macil, a hematite mining company nearby), and Arthur (another homesteader living within the plantation); all attempted, at first unsuccessfully, to identify the stones (A. Tavares, J. Drew, L. Nercessian, pers. comm., 1987).

In the meantime, Rodazio sold his ever-growing collection of "andalusite" to a visiting Teófilo Otoni gem dealer, Joaquim Feijão. Feijāo's suspicions were confirmed when he took the rough to Teófilo Otoni: This was indeed alexandrite - and among the best anyone had seen from Brazil. As he sought the source, he eventually met Socrates, Arthur, Xisto, and Policarpo, who by now were all attempting to dig some of the rough. In November 1986, two Brazilian companies headed by Socrates and Xisto almost simultaneously requested an exploration permit from the government to open the alexandrite occurrence. By December, after much squabbling among themselves, the two groups combined their efforts and began mining the area by hand (as yet without the official government license). They agreed to keep the new discovery quiet for fear garimpeiros would invade the property. Although Ferro Brasileira owned almost all of the land, the mining rights in Minas Gerais belong to the state and any licensed garimpeiro can invade the property and mine at will.

Infighting and clandestine digging continued until the first big parcel-21.5 grams-arrived in Teófilo Otoni on January 28, 1987, and was shown to A. Tavares, K. Elawar, and other prominent dealers. Each recognized that this was among the finest alexandrite ever seen and sensed the real importance of the find. On February 8, the first five faceted stones (totaling only $1 \mathrm{l} \mathrm{ct}$ ) sold for US $\$ 40,000$ to Japanese buyers (A. Tavares, pers. comm., 1988). By February I5, several dealers and garimpeiros had discovered the location of the deposit. By March 15, the trickle of garimpeiros had turned into a flood; by the end of March, 3,000 pit diggers had invaded this very small valley deposit (see figure 13). A tent city sprang up 


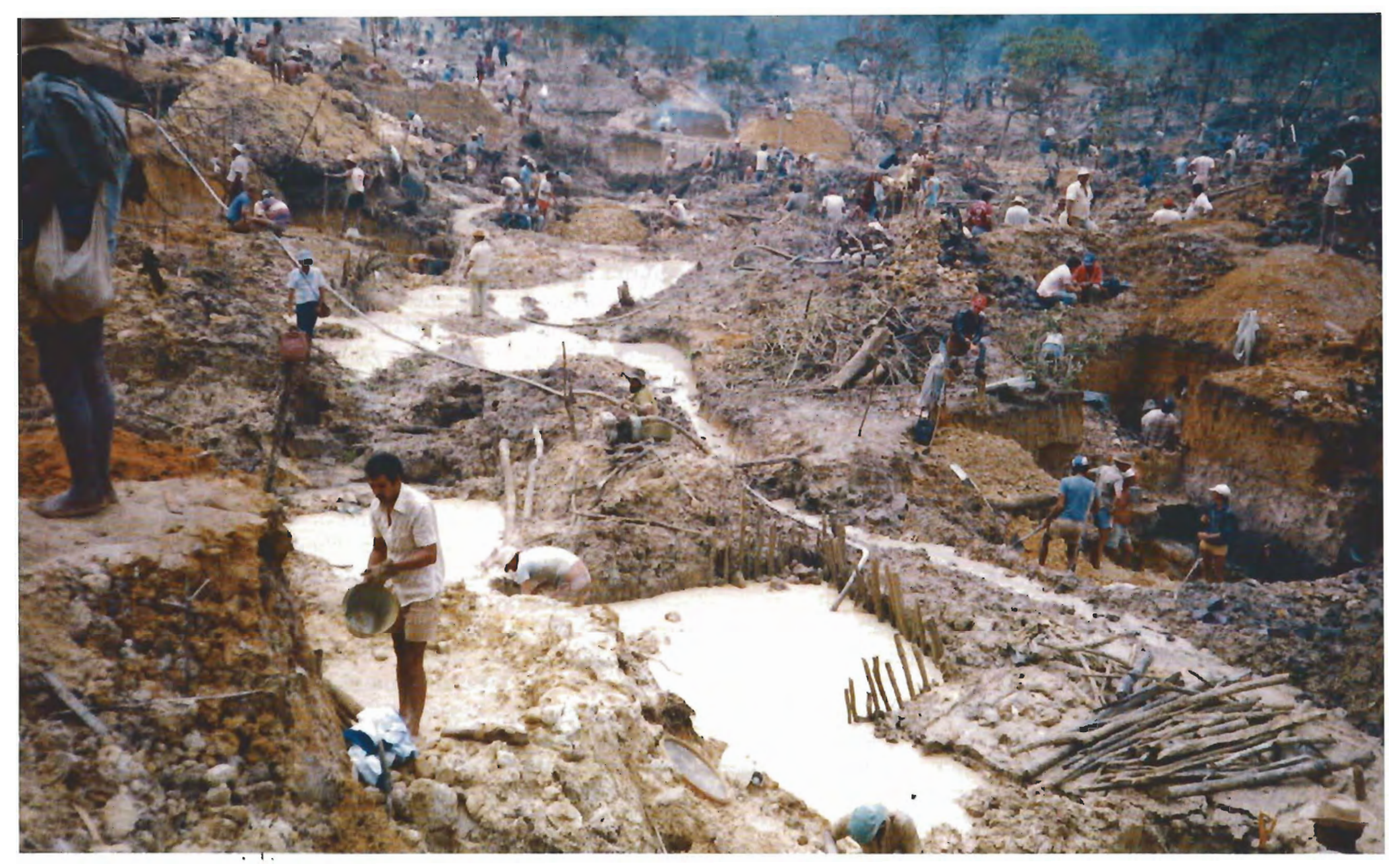

Figure 13. Within a matter of weeks after the Hematita deposit was discovered by local miners and dealers, both sides of this meandering brook, and even the brook itself, were invaded by thousands of miners. Note in the pit on the right the clear demarcation of three layers-an overburden of clay and sand, the heavily quartz-and kaolin-bearing gem gravel, and a dark layer of what appears to be clay below that. The apex of this small, triangular-shaped valley pinches in at the top of the photo. Photo by Agenor Tavares.

overnight with extremely primitive living conditions.

At the mine, pandemonium broke out as each garimpeiro attempted to stake out a few square meters for himself. There was not enough land to go around and huge fights, including gunplay, erupted. In their frenzy to get their share, many garimpeiros dared not leave their pits, even to buy food; they slept virtually standing or sitting up, body to body (R. Nash, pers. comm., 1987). The men were so close together that a shovel of clay or dirt thrown anywhere infringed on a neighbor's rights and sensibilities.

This extremely intense digging activity, plagued by arguments, outbreaks of violence, and numerous robberies (as professional thieves also invaded the areal continued for almost three months. The stakes were high: The equivalent of approximately US\$5 million was spent on alexandrites at or near the mine during this period ( $\mathrm{L}$.
Nercessian and K. Elawar, pers. comm., 1987). One small handful of rough from one little pit could take a garimpeiro from abject poverty to instant wealth. As usual, though, many garimpeiros received little or none of this treasure and were unable even to make expenses; several team leaders of groups of 20 to 30 miners reported that they did not find one piece (K. Elawar, pers. comm., 1987).

Most of the alexandrites were found during these three months, with the best $70-80 \%$ coming out between April 15 and May 15. Eventually, though, the violence became so widespread that the military police were called in. On June 18 , the area was "closed."

After the "closure," many of the garimpeiros stayed, hoping that the area would reopen at any time. With no production, money, food, or sanitary facilities, it did not take long for an ugly mood to develop. The federal military police put up a 
barbed wire fence around the entire mining area, but most of the remaining miners were willing to risk everything for a chance to dig. The reader can imagine the situation of 60 to 100 military police trying to control thousands of hungry and angry miners. They became more brazen after dark, and every night many (sometimes hundreds) of miners would go through the fences and mine by moonlight, which resulted in several shootings. Many who were there to maintain control were seen digging in the pits themselves.

The mine remained "closed" in this fashion until August 18, when Warren Brennan, a geologist and gemstone dealer from Los Angeles, arrived with a group of people, including 10 federal plainclothes police and a judge from Hematita. This group "re-opened the mine," and 150 of the 800 garimpeiros who still remained outside were let in late that afternoon, with another 150 allowed in the following day. On the 20th, 2,000 more miners returned, expecting open mining to start again; a line of parked cars more than a kilometer long dominated the scene. Violence ensued almost immediately, and the army closed the area again on August 23.

That night was one of the most violent in Minas Gerais mining history. The garimpeiros set fire to the eucalyptus forest opposite the mining area, and even to several cars. At least one soldier was shot and approximately two dozen miners were wounded in the fighting that ensued (D. Schwartz and W. Brennan, pers. comm., 1987). Between 10 and 15 people have died at these diggings so far. On August 24, the military police rerouted one of the creeks and flooded most of the mining area so that it was virtually unworkable.

On October 1, with special permission from the Minister of Mines, 60 to 70 members of the International Gemmological Conference (IGC) visited the closed mine (Koivula, 1987), but were allowed to stay only 45 minutes. Although the mine remains "closed" / with periodic clandestine digging) at this writing (February 1988), it was scheduled to reopen officially in March 1988 (D. Schwartz, pers. comm., 1988).

Geology and Occurrence. It is important to visualize just how small this deposit is. The mining area is only $200 \mathrm{~m}$ long by $150 \mathrm{~m}$ wide (approximately 650 by $500 \mathrm{ft}$.), with the diggings extending over a roughly oval area. However, $70-80 \%$ of the choicest rough came from a triangular-shaped area only
$500 \mathrm{~m}^{2}$ (again, see figure 13). Two small brooks cut through this alluvial deposit and meet at the center of the richest find (S. Domingos, pers. comm., 1987). This brook divides again and then rejoins before leaving the deposit area, at which point it passes over a waterfall and empties into the Córrego do Liberdade (Liberty Creek), which runs almost perpendicular to the fall line of the valley itself. Significantly, little or no gem alexandrite was found below the Córrego do Liberdade, although a backhoe operation near this creek did yield small amounts of rough.

At least four geologists and/or mining engineers have visited this deposit. They have identified three distinct "environments" (and variations thereof; again, see figure 13) containing the gembearing gravel layers.

In part of the valley, Dr. Rex Nash found evidence of the typical Marambaia-type alluvial deposit (see, e.g., Proctor, 1984), with the gembearing gravels probably lying on top of bedrock and under interbedded layers of sand and clay. Unlike the granite pebbles and boulders of Barro Preto, 99\% of the gem-bearing gravel in this area appeared to be rolled quartz pebbles in sizes of 2 to $10 \mathrm{~cm}$ (1 to 4 in.). Dr. Nash noted that the overburden-mostly clay with some sand and only a small amount of red soil-was 1.5 to $2 \mathrm{~m}$ thick.

Another geologist, Sabastião Domingos, noted that elsewhere in the deposit the cascalho layer averaged $50 \mathrm{~cm}(20 \mathrm{in}$.) thick and varied from 1 to 5 $\mathrm{m}$ below the surface. Domingos also reported a 20 $\mathrm{cm}$-thick layer of sand-which also contained fragments of alexandrite-approximately $1 \mathrm{~m}$ above the main cascalho layer.

Warren Brennan noted quite different conditions in a separate region of the same narrow valley. The exposed walls of several pits over $3 \mathrm{~m}$ deep showed three distinct quartz-pebble gravel layers. The top layer began approximately $30-60 \mathrm{~cm} / 1$ to $2 \mathrm{ft}$.) deep under the surface clay layer (with very little sand showing) and was 30-45 cm thick. Under that was another $30-45 \mathrm{~cm}$ layer composed mostly of clay, which overlay the middle gravel layer, $30-45 \mathrm{~cm}$ thick. Another clay layer, over 30 $\mathrm{cm}$ thick, covered the bottom gravel layer almost 3 $\mathrm{m}$ below the surface. Some clay was found in the three predominantly quartz layers, and some quartz in the clay layers. The quartz layers also contained significant amounts of kaolin. Brennan examined about eight piles of previously washed quartz pebbles from all three layers and noted that 
most of the pebbles ranged between 1 and $10 \mathrm{~cm}$. Half were about $90 \%$ rounded, with the rest only slightly (perhaps 10\%) rounded. Brennan found one $7.5-\mathrm{cm} \quad(3-\mathrm{in}$.$) perfectly terminated quartz$ crystal.

The three quartz-pebble layers undoubtedly represent three different periods of deposition. The top two quartz-pebble layers, lying on clay layers, are apparently colluvial deposits similar to those found at Barro Preto. The interbedded layers of clay and quartz, and the extremely high concentrations of kaolin clay (figure 14), are seldom if ever seen in a purely alluvial environment, where the swift waters typically wash most of it away.

Much of the alexandrite also showed sharp edges or, frequently, one complete crystal face, as well as a number of complete crystals, some twinned and some as large as $1.4 \mathrm{~cm}$ (L. Nercessian, A. Tavares, K. Elawar, and K. Schmetzer, pers. comm., 1987). The good crystalline condition of some of the quartz, the abundant alexandrite fragments with sharp edges and crystal faces, and the great amounts of kaolin indicate that the deposit moved less than $100 \mathrm{~m}$ downstream after it eroded and weathered out of the hillside in which it had formed (R. Nash, pers. comm., 1987). Or, as at the Salinas tourmaline deposit (Proctor, 1985a), the Hematita alexandrites actually may have moved very little but rather decomposed in place as the hillside in which they were originally contained eroded and became part of the valley floor (R. Nash, pers. comm., 1987).

Nash believes that several factors strongly suggest that this alexandrite deposit, unlike the others reported in the literature (e.g., the Urals, Itabira, Carnaíba, etc.), may actually have formed in a pegmatite. Although the presence of quartz, kaolin (from weathered feldspar), and even aquamarine-which are commonly associated with pegmatites - could be explained by the weathering of pegmatites in the granite host rock at the same time as the alexandrite, the large pieces of clean alexandrite found are typical of pegmatite mineral crystallization, as is the unusually large proportion of transparent material. Again, though, no alexandrite crystals have been found in situ, so further study is needed.

Statements by some dealers closely associated with this mining operation strongly suggest that most of the best gems were found in the lower, truly alluvial bedrock gravels of this valley, just as they were at Barro Preto, Gil, Marambaia, and Tres

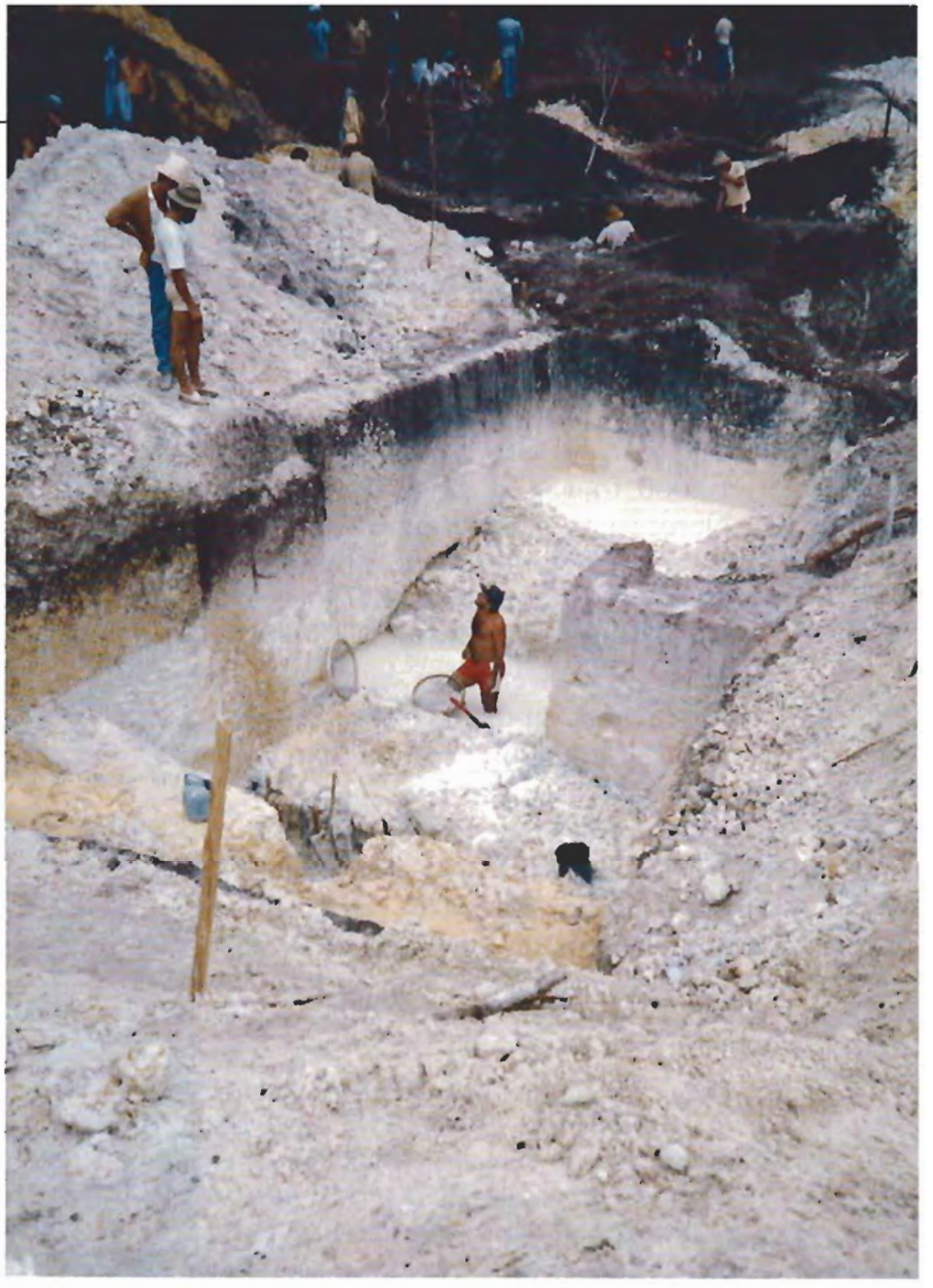

Figure 14. Great quantities of kaolin (decomposed feldspar) were found at Hematita, turning many of the pits almost completely white. Photo by Agenor Tavares.

Barras (K. Elawar and A. Tavares, pers. comm., I987).

Mining. The first diggings in the surface dirt here involved just pick and shovel work, with the soil and clay being washed with screens in the nearby creeks. This method quickly evolved into the excavation of square pits as deep as 5-6 m (D. Schwartz and S. Domingos, pers. comm., 1987; again, see figures 13 and 14). After the garimpeiros dug their pits and extracted what gravels they could, they let the pit fill up with water and began the tedious washing operation with circular screens. More sophisticated garimpeiros used two "stacked" screens, with different meshes, for better sorting. Pumps were necessary to keep most of these pits workably dry (figure I5). Most of the areas mined were worked by hand. 
Production. As with most gem deposits in Minas Gerais, production statistics are elusive, but major dealers estimate that approximately $50 \mathrm{~kg}$ of alexandrites have been found at Hematita thus far. Of this, however, only approximately $10 \mathrm{~kg}$ show the best clarity and color change, resulting in 10,000 to 15,000 ct of fine to superior gems (L. Nercessian, pers. comm., 1987). Some clean, large pieces of 16 and 20.5 grams yielded almost exactly $50 \%$ when cut (K. Elawar, pers. comm., 1987). Several clean or mostly clean pieces of rough of 17 to 56 grams were also seen by H. Bank, K. Elawar, A. Tavares, and L. Nercessian, but most of the rough found weighed less than 1 gram (L. Nercessian, pers. comm., 1987).

Several large faceted alexandrites - many over $10 \mathrm{ct}$ and at least one as large as $30 \mathrm{ct}$-have been cut from the Hematita rough. A few superb cat'seye alexandrites over $10 \mathrm{ct}$ were also cut (K. Elawar, pers. comm., 1987). The bulk of the material was

Figure 15. Pumps were required to rid most of the pits of water at Hematita. Note also the many circular screens, which the miners use to wash the gravels in their search for the gem alexandrites. Photo by Agenor Tavares.

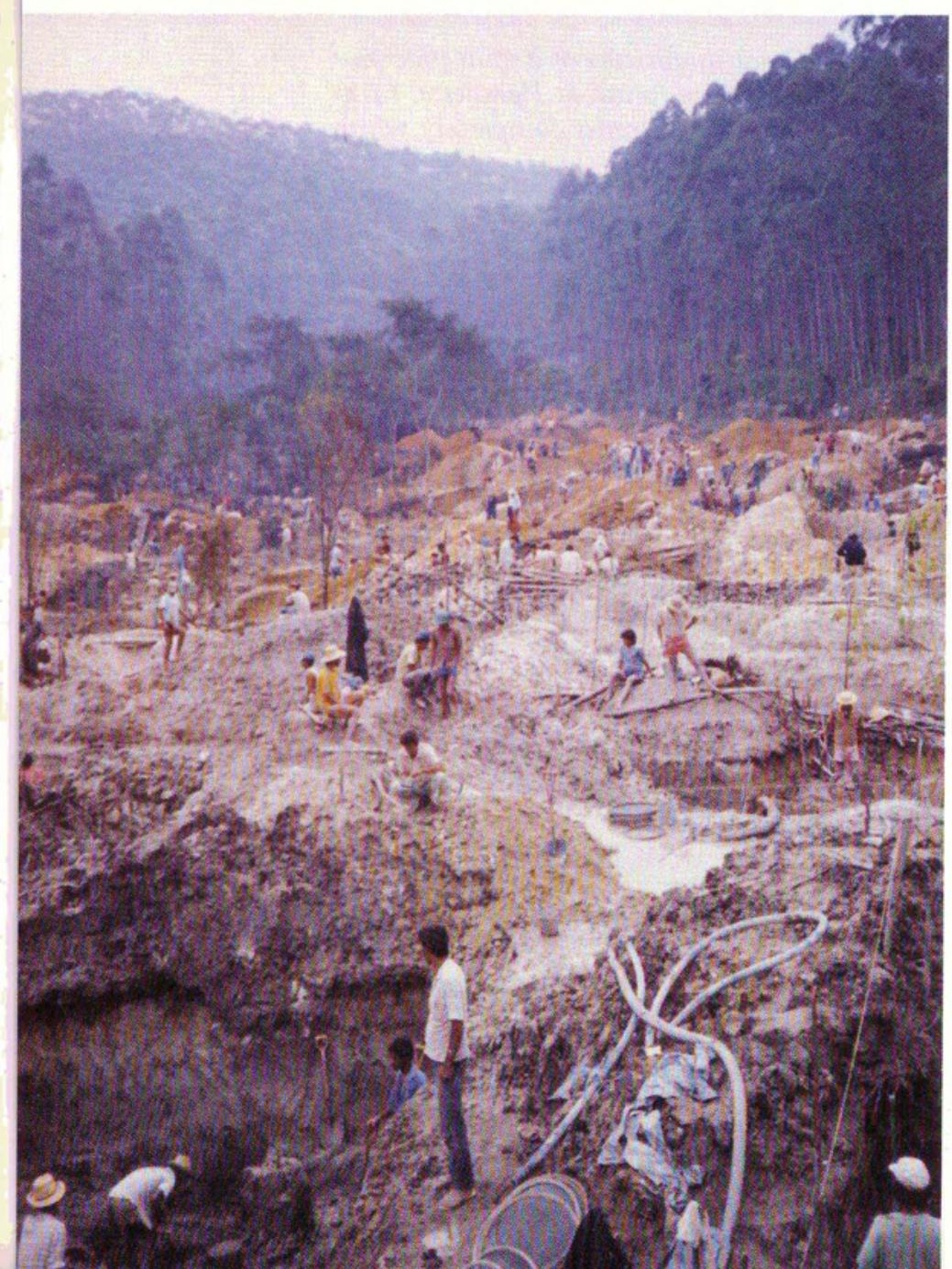

faceted into many thousands of medium to very fine stones between 0.20 and $6 \mathrm{ct}$. One- to 2-ct stones were abundant, but 3-ct and larger stones made up no more than $15 \%$ of the total number. Roughly $50-60 \%$ of all sizes, and especially the very small sizes, are "clean" (K. Elawar, pers. comm., 1987), with 40-45\% exhibiting a good color change from greenish blue to some shade of pink or red. Some stones that display a very attractive color change are far from clean $(\mathrm{K}$. Elawar, pers. comm., 1987).

The lion's share of the production was purchased by four companies: K. Elawar, Ltda., Tamil (owned by A. Tavares), and the two companies owned by the two brothers Hilton (Zequinha) Lopes and Lopes Duarte. As of January 1, 1988, roughly one-third of the total production remained in Teófilo Otoni. About 40\% had gone to Hong Kong and Japan, German buyers had purchased approximately $20 \%$ of the total, and the remainder was sold primarily to American buyers (K. Elawar and L. Nercessian, pers. comm., 1987). Although much of the valley floor was dug up, it appears that many sections remain untouched (D. Schwartz and L. Nercessian, pers. comm., 1987). However, clandestine digging during 1988 has produced little of value (R. Nash, pers. comm., 1988), which raises some questions as to the true potential of the deposit.

The Hematita Alexandrites. The Hematita alexandrites contain $0.30-0.44$ wt. $\% \mathrm{Cr}_{2} \mathrm{O}_{3}, 1.11-1.59$ wt. $\% \mathrm{Fe}_{2} \mathrm{O}_{3}$, and 0.01-0.03 wt. $\% \mathrm{~V}_{2} \mathrm{O}_{3}$ (H. Bank and K. Schmetzer, pers. comm., 1987). The best Hematita gems compare very favorably with the best Russian material: greenish blue to blue in sunlight and pink to red in incandescent light (figure 16). Since alexandrite is trichroic, the best color can be achieved only if the cutter uses the correct orientation of the gem's table in relation to the c-axis.

The best pink to red colors exhibited by this gem in incandescent light are invariably coupled with a very distinctive slightly greenish blue to blue color the Brazilians call pavão (peacock). The best (or most complete) color change involves pavão in sunlight changing to a strong pink, raspberry, or deep "rhodolite" or "ruby" red in incandescent light. About $30 \%$ to $45 \%$ of the best $10 \mathrm{~kg}$ exhibited this color change (K. Elawar, pers. comm., 1987).

A more greenish or yellow-green color in 


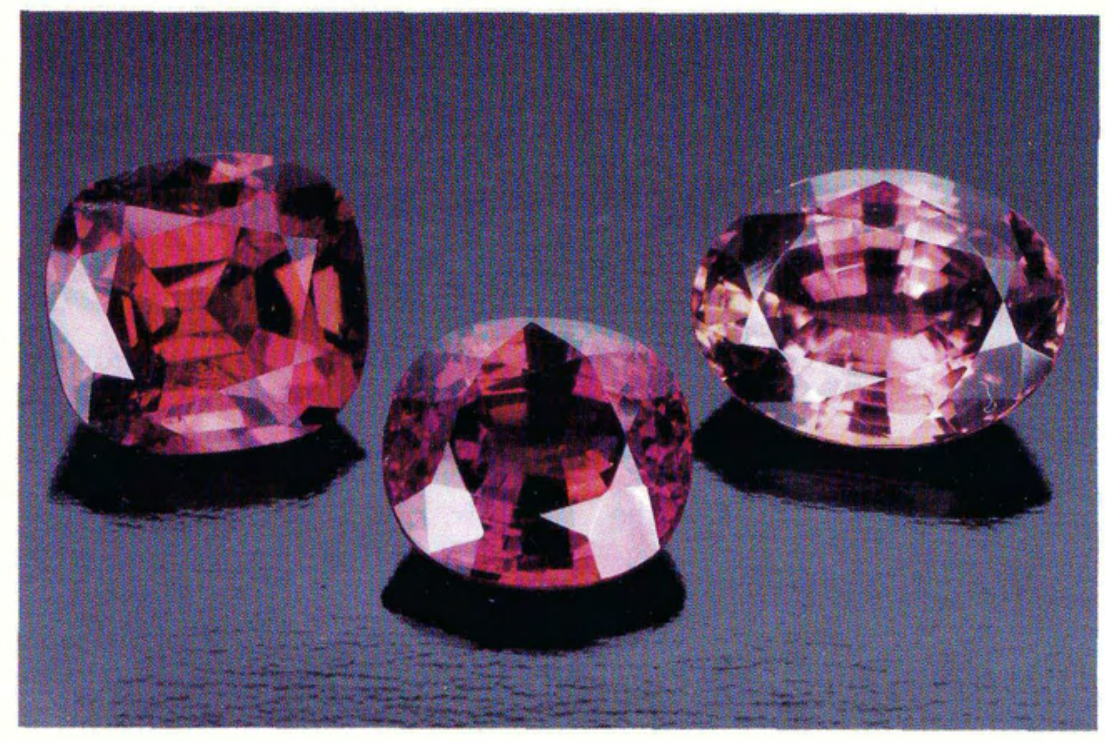

Figure 16. The color change of the two Hematita alexandrites $(1.06$ ct-center, 1.32 ct-right) is very similar to that of the fine Russian stone $(1.29 \mathrm{ct})$ on the left. The photo at the top was taken with incandescent light; the one at the bottom with fluorescent light. The two Hematita alexandrites are courtesy of Mayer \& Watt; the Russian alexandrite is courtesy of Mary Murphy Hammid. Photo (c) Tino Hammid.

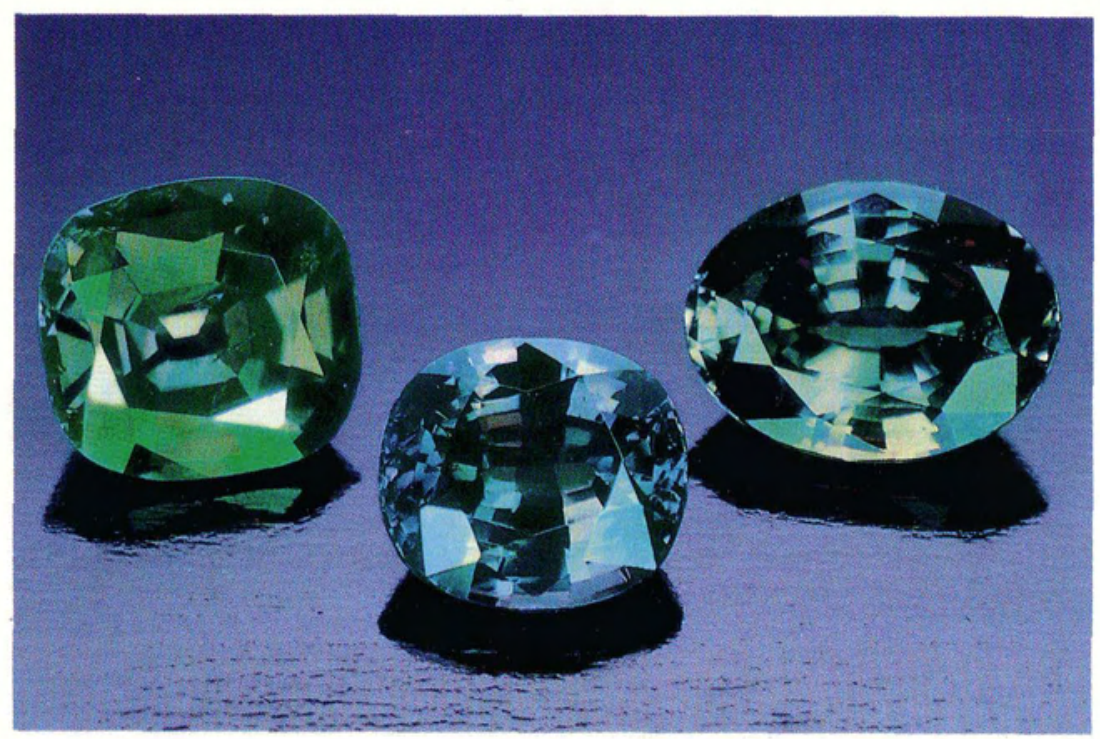

sunlight is usually coupled with more purplish tones in incandescent light, while a very dark blue (with some brown or even a gray-brown) as the predominant daylight color is usually associated with a dark brownish red or reddish purple in incandescent light (K. Elawar and A. Tavares, pers. comm., 1987).

With the increased interest in alexandrites stimulated by the Hematita discovery, there appear to be more synthetic alexandrites on the market. The buyer is advised to be aware of the distinctions between natural and synthetic alexandrites before he or she purchases any stone (see, for example, Stockton and Kane, 1988). Inclusions observed in the Hematita alexandrites include apatite, fluorite, mica of the biotite group, and twoand three-phase inclusions (E. Gübelin, H. Bank,
K. Schmetzer, and H. Hänni, pers. comm., 1988; see Koivula and Kammerling, 1988, for photomicrographs).

\section{OTHER CHRYSOBERYL AND ALEXANDRITE DEPOSITS IN BRAZIL}

In Minas Gerais, small amounts of chrysoberyl have also been found near Santo Antônio do Jacinto, located on the border with Bahia. In 1972, a six-month production from Lavra dos Coímbras, southwest of the Americana/Santana valley region, yielded significant amounts of alexandrite (H. Kennedy and A. Tavares, pers. comm., 1987). In August 1987, small amounts of small but clean alexandrite were taken from another location in the Hematita region, approximately $8 \mathrm{~km}$ in the 
direction of the city of Antônio Dias (and referred to by that name). Other deposits are shown on the map in figure 4.

Quite a few locations in the state of Bahia have produced chrysoberyl and/or alexandrite, including Sócota, Jaguda, and Jacundá (principally alexandrite; H. Bank, pers. comm., 1987) as well as Jaqueto (chrysoberyl and some alexandrite; the 6,250-gram [20 cm high] Mitra [or Bishop's hat] cat's-eye was found here as was a $25.2-\mathrm{kg}$ chrysoberyl crystall. The Carnaiba emerald mine (in the Campo Formosa area) produced some primarily low-quality alexandrite and some superb sixling crystals. Chrysoberyl or alexandrite has been found near the cities of Aguas Frias, Itanhém, Teixeira de Freitas, Cachoeira do Mato, Itamaraju, Faria Lemos, and on the Córrego de Água Preta (J. Raggi and A. Lúcio, pers. comm., 1987). In southern Bahia, Lagôa da Prata has produced approximately $10-15 \mathrm{~kg}$ of alexandrite with a light green to pink color change, and consistently produces chrysoberyl and cat's-eye chrysoberyl (K. Elawar and H. Kennedy, pers. comm., 1987).

Several locations in the state of Espírito Santo also produce chrysoberyl and cat's-eye chrysoberyl (but insignificant amounts of alexandrite): the Colatina region is represented by São João Grande and lime-green stones from Municipio de Vila Panca; the Itacriso mine, $40 \mathrm{~km}$ west of Colatina, has been one of the largest producers outside Minas Gerais (J. Raggi and L. Nercessian, pers. comm., 1987). Mineral collectors know the famous deposit at Itaguaçu, some $35 \mathrm{~km}$ southwest of Colatina, where a few superb cyclic sixling chrysoberyl twin crystals (called trillings) as large as $9.5 \mathrm{~cm}$ were found |"Interview: Allan Caplan," 1980).

\section{CONCLUSION}

For the past 50 years, the Americana and Santana valleys have been one of the most productive regions in the world for chrysoberyl and cat's-eye chrysoberyl. The Faísca and Cilindro deposits, together with the Barro Preto and Gil claims, are the largest and most consistent producers in the region. Exceptional alexandrites and cat's-eye alexandrites have also been found in this region, at the Coímbras deposit.

Since 1975, the Malacacheta region has developed into one of the world's premier alexandriteproducing areas. In 1987, however, the production at Malacacheta was eclipsed in size and quality by the gems found at Lavra de Hematita, which is probably the single most significant alexandrite deposit in history.

Throughout this series of articles on gems from the pegmatite districts of Minas Gerais, we have observed how gem rough occurs in a great variety of environments. Primary, in situ deposits are not common but often produce the finest materials (see, e.g., the Jonas rubellite mine, Proctor, 1985b). Most primary deposits have decomposed over time, so that the gems are found dispersed in secondary deposits with either kaolinclay (see, e.g., the Santa Rosa and Golconda III tourmaline mines; Proctor, 1985b) or red soil, which represents a further degree of dispersal (see, e.g., the Ouro Fino tourmaline mine as well as the Pioneer and Pine Tree aquamarine mines; Proctor, 1984, 1985a). In all of the chrysoberyl and alexandrite deposits discussed in this article, we have witnessed the complete dispersal of gems into alluvial as well as colluvial gravels.

\section{REFERENCES}

Ball S.H. (1930) Historical notes on gem mining. Economic Geology, Vol. 26, pp. 681-738.

Bank H. (1973) From the World of Gemstones. Unschau-Verlag, Frankfurt am Main, W. Germany.

Bauer M. (1904) Precious Stones. Reprinted by Dover Publications, New York, 1968.

Desautels P.E. (1979) Treasures in the Smithsonian, the Gem Collection. Smithsonian Institution Press, Washington, DC.

Interview: Allan Caplan (1980) Mineralogical Record, Vol. 11, No. 6, pp. 351-360.

Koivula J. (1987) Gem News: More on Brazilian alexandrites. Gems \&) Gemology, Vol. 23, No. 4, pp. 238-240.

Koivula J., Kammerling R. (1988) Genı News: Inclusions identified in new Brazilian alexandrites. Gems e) Gemology, Vol. 24, No. 1, p. 56-59.

Kunz C.F. (1913) The Curious Lore of Precious Stones. Reprinted by Dover Publications, New York, 1971.

Pough F, (1973) Three fashionable minerals. Mineral Digest, Vol. 5, pp. 25-32.

Pough F. (1976) Alexandrite: Gem named for a crown prince. Mineral Digest, Vol. 8, pp. 69-73.

Proctor K. (1984) Gem pegmatites of Minas Gerais, Brazil: Exploration, occurrence, and aquamarine deposits. Gems (4) Gemology, Vol. 20, No. 3, pp. 78-I00.

Proctor K. (1985a) Gem pegmatites of Minas Gerais, Brazil: The tourmalines of the Araçuai districts. Gems \&) Gemology, Vol. 21, No. 1, pp. 3-19.

Proctor K. (1985b|Gem pegmatites of Minas Gerais, Brazil: The tourmalines of the Governador Valadares district. Gems (4) Gemology, Vol. 21, No. 2, pp. 86-104.

Sinkankas J. (1964) Mineralogy for Amateurs. Von Nostrand Co., Toronto, Canada.

Stockton C., Kane R. (1988) The distinction of natural from synthetic alexandrite by infrared spectroscopy. Gems e) Gemology, Vol. 24, No. 1, pp. 44-46.

Webster R. (1983) Gems, 4th ed. Butterworths, London. 